This is the author's final, peer-reviewed manuscript as accepted for publication. The publisher-formatted version may be available through the publisher's web site or your institution's library.

\title{
Is food security a new tariff? Explaining changes in sanitary and phytosanitary regulations by World Trade Organization members
}

Raymond Kassatly, Andrew G. Long, Justin Kastner

How to cite this manuscript

If you make reference to this version of the manuscript, use the following information:

Kassatly, R., Long, A. G., \& Kastner, J. (2013). Is food security a new tariff? Explaining changes in sanitary and phytosanitary regulations by World Trade Organization

members. Retrieved from http://krex.ksu.edu

\section{Published Version Information}

Citation: Long, A. G., Kastner, J. J., \& Kassatly, R. (2013). Is food security a new tariff? Explaining changes in sanitary and phytosanitary regulations by World Trade Organization members. Global Economy Journal, 13(1), 25-46.

Digital Object Identifier (DOI): doi:10.1515/gej-2012-0025

Publisher's Link:

http://www.degruyter.com/view/j/gej.2013.13.issue-1/gej-2012-0025/gej-2012-0025.xml

This item was retrieved from the K-State Research Exchange (K-REx), the institutional repository of Kansas State University. K-REx is available at http://krex.ksu.edu 


\section{Is Food Security a New Tariff? Explaining Changes in Sanitary and Phytosanitary Regulations by World Trade Organization Members}

Raymond Kassatly | former research assistant, Frontier program, Kansas State University, Manhattan, Kansas 66506, USA.

Andrew G. Long, PhD | Associate Professor, Department of Political Science, 228b Waters Hall, Kansas State University, Manhattan, Kansas 66506, USA. aglong@k-state.edu

Justin Kastner, PhD | Assistant Professor, Department of Diagnostic Medicine/Pathobiology, 310 Coles Hall, Kansas State University, Manhattan, Kansas 66506, USA; co-director, Frontier program for the historical studies of border security, food security, and trade policy (http://frontier.k-state.edu). jkastner@k-state.edu

ABSTRACT: Scholars at the intersection of agricultural trade policy and health regulation have speculated that some governments, under the pretext of health protection, have adopted food safety and plant and animal health regulations to shield domestic farmers from foreign competition. In this paper, we investigate the relationship between trade protection for agriculture and the number of trade-restricting sanitary and phytosanitary (SPS) regulatory notifications issued by World Trade Organization (WTO) members. We construct an empirical model to determine the influence of agricultural protectionism, agricultural interest groups, consumer sentiment, and institutional capacity on changes to a government's SPS rules. The findings suggest that governments' adoption of trade-restricting sanitary and phytosanitary regulations are influenced by agricultural protectionism, even after controlling for consumer awareness and institutional capacity. The evidence suggests that health related trade policies are substituting for more traditional forms of agricultural protectionism.

KEYWORDS: World Trade Organization, SPS Agreement, sanitary and phytosanitary notifications, agricultural protectionism, consumer welfare, consumer awareness, institutional capacity 


\section{INTRODUCTION}

The completion of the Uruguay Round of Multilateral Trade Negotiations in 1994 resulted in the adoption of the World Trade Organization Agreement on the Application of Sanitary and Phytosanitary Measures (SPS Agreement) (WTO, 1998b, p. iii). Amongst other provisions and requirements, the SPS Agreement requires governments to notify other World Trade Organization (WTO) member countries of new or anticipated food safety, animal health, or plant health regulations which may affect agricultural trade (WTO, 1998a). Article 7 of the SPS Agreement states, 'Members shall notify changes in their sanitary or phytosanitary measures and shall provide information on their sanitary measures' (WTO, 1998a, p. 36).

While ostensibly employed to protect agricultural and public health, sanitary and phytosanitary (collectively termed 'SPS') regulations may also simply be 'disguised barriers to trade' (Moy, 1999, p. 21). Existing research reports on specific individual scenarios in which SPS measures resulted in overprotection and exceptional barriers to agricultural trade (James and Anderson, 1998, Kastner and Powell, 2002, Otsuki et. al., 2001). We build on previous investigations by examining whether SPS regulations provide nation-states with a convenient pretext to disguise what is actually agricultural protectionism. The number of SPS notifications submitted to the WTO varies between countries (Henson et al., 2003, Cash et al., 2004, OECD, 2004a) and it remains a difficult but important task for trade policy scholars to discern national governments' motivation for issuing SPS notifications.

Consequently, we hypothesize that SPS notification activity is correlated with the amount of protectionism afforded traded agricultural products and with the level of demand for protectionism by agricultural producers. To test our claims, we assemble a dataset recording the annual number of SPS notifications by each member of the SPS agreement from 
1996-2005. The evidence supports the hypotheses proposed in this paper. Specifically, as the relative rate of assistance to agriculture increases, the number of SPS notifications by the country decreases. In addition, increases in the productivity of agriculture are associated with decreases in the number of SPS notifications. These results are robust across developed and developing economies and including measures for a government's capacity to implement regulations and the level of consumer awareness (and demand) for food, animal, and plant health and safety.

There are several reasons to study whether SPS regulatory notifications are rooted in agricultural protectionism. First, SPS notifications may constitute major trade impediments, and a general assessment of the welfare impact of SPS notifications would be instructive should the SPS Agreement ever be revisited in a future round of multilateral trade negotiations. Second, determining whether SPS notifications are protectionist in general is important in the regulatory reform process in OECD countries (OECD, 1997). Third, technical SPS-related regulations in developed countries may very well pose an obstacle to agricultural food exports from developing countries (Lutz and Lutz, 2009, Otsuki et al., 2001). During the Uruguay Round, developing countries viewed access to Northern markets-including those in the food sector-as a compelling reason to assent to the multilateral, rules-based system. A decade later, developing countries lament that, in fact, access to Northern markets did not improve, and they place some of the blame on technical import requirements (Messerlin 2005). ${ }^{1} \mathrm{~A}$ better understanding of the effects of SPS-related trade barriers could help address developing countries' concerns and inform the multilateral negotiation process (Henson et al., 2003, OECD, 2004a).

\footnotetext{
${ }^{1}$ A thorough overview of the issues surrounding agricultural trade liberalization can be found in the Global Economy Journal, Volume 5, Issue 4 (Stern, 2005)
} 
This paper investigates the link between agricultural protectionism and increases the number of SPS notifications issued by WTO member governments. The first section of the paper reviews the literature regarding SPS regulations, consumer awareness, and agricultural protectionism. The second section in the paper describes the variables used to determine whether SPS measures do, in fact, exert agricultural-protectionism pressures. Several economic and political variables are used to predict the relationship between SPS notifications and agricultural protectionism. Literacy rates and institutional indices are used as control variables to determine, respectively, the effect of consumer awareness and institutional capacity on SPS regulations. The third section of the paper provides a discussion of the results obtained in the analysis. In the final section, the paper discusses the results' policy implications for future multilateral trade negotiations.

\section{Food SAFETY AND THE SPS AgREEMENT}

SPS regulations include measures to protect food safety, animal health, and plant health. Heightened consumer awareness, brought on by increasing scientific understanding of both real and perceived health-related concerns in the food supply (Ewen et al., 2006), greatly influences the adoption of food safety regulations by national governments and consumers' food safety views manifest themselves in terms of SPS-related policies. For example, consumer perceptions regarding genetically modified (GM) foods differ between the United States (US) and Europe leading to and transatlantic regulatory differences (Ganiere and Chern, 2004). Levels of consumer awareness are similarly influential in the developing world (Kimenju and de Groote, 2008, Umali-Deininger and Sur, 2007, Wang et al., 2008). 
Because citizens hold their governments accountable for ensuring that foods procured both domestically and internationally meet certain standards, complex regulatory regimes exist to: 1) support the public good of food, animal, and plant health and safety, and 2) regulate food production and exchange by lowering transaction costs. Furthermore, to the extent that SPS regulations enhance the efficiency of the agri-food sector, they may be deemed economically beneficial. For instance, controlling animal or plant health hazards often cannot be accomplished by individual producers (destroying a single diseased animal in a herd, for example, has positive consequences for other herds); therefore, governments may adopt intervention policies that encourage eradication (Brown et al., 2002). In addition, when information about health or quality characteristics is unknown or asymmetrically distributed between producers and consumers, regulations can improve the functioning of markets (Darby and Karni, 1973).

Consequently, many SPS regulations that place legitimate restrictions on trade are social welfare-enhancing. Nevertheless, SPS regulations are increasingly appearing at the center of trade disputes because SPS regulations may also be used to shield farmers and industries from foreign competition. ${ }^{2}$ The WTO acknowledges the dilemma over whether SPS regulations signal protection or protectionism and admits that, "governments are sometimes pressured to go beyond what is needed for health protection and to use sanitary and phytosanitary restrictions to shield domestic producers from economic competition" (WTO, 1998b, p. 6). The SPS Agreement specifically addresses this dilemma. It expressly allows countries to set their own food safety, animal health, and plant health standards and regulations, but stipulates that the

\footnotetext{
${ }^{2}$ Food safety or animal health concerns have a lengthy history of effective use as protectionist tools (see, e.g. Gignilliat, 1961, Snyder, 1945).
} 
regulations be applied in a consistent manner and only to the extent necessary to protect human, animal, or plant life or health (WTO, 1998b).

While the SPS Agreement attempted to pre-empt trade disputes over SPS measures, it has not prevented countries from using certain arbitrary measures to impede trade. Several other studies note SPS measures that unduly restrict trade (Calvin and Krissoff, 1998, Orden, et. al., 2001, Otsuki et al., 2000, Snape and Orden, 2001, Henson et al., 2003, Josling et al., 2004). For example, Otsuki et al. (2001) describe the effect of a proposed EU regulation on maximum allowable aflatoxin levels for cereals, dried and preserved fruits and vegetables, and edible nuts. The new regulation, compared to a less-stringent, internationally developed standard, would generate a loss of US\$220 million-a 47 percent reduction over previous trade. According to estimates from the Food and Agriculture Organization of the United Nations (FAO), the number of lives that the more-stringent EU regulation would save was vanishingly small-0.9 lives per 1 billion persons (Otsuki et al., 2001).

The SPS Agreement affirms countries' sovereign right to adopt their own appropriate levels of health protection (ALOPs) as long as they are consistently applied, non-discriminatory, and not more trade restrictive than necessary (Kastner and Powell, 2002). While previous scholarship on the potential for SPS regulations to be protectionist examines individual regulations on a case-by-case basis, it would also be useful to know if the SPS regulatory behavior of countries conforms to scholars expectations about when and where protectionist behavior is likely to occur. In the next section, we review the theoretical and empirical research on agricultural protectionism to develop hypotheses about the relationship between SPS regulatory behavior and agricultural protectionism. 


\section{Theories And Evidence in the Study of Agricultural Protectionism}

If some SPS regulations are substituting for 'traditional' forms of protectionism, theories of protectionism could explain variation in SPS regulatory activity. Research on agricultural protectionism generally fits one of four categories. The first category represents collective action theories (Olson, 1965, Becker, 1983). Small groups with specialized interests are easier to organize and more effective in securing economic rents than large groups with larger interests (Olson, 1965). Consumer groups suffer from free-rider problems that make it difficult to oppose rent-seeking by agricultural producers. Collective action theories explain why the US and EU subsidize farmers even though they taxed farmers before the industrial revolution, and why developing countries are currently taxing agriculture (Olson, 1985, 1990). According to Olson (1985), agricultural producers can succeed in being shielded from foreign competition despite variation in their size and interests because of common interests among producers in greater protection that will be paid for by consumers. His explanation focuses on factors affecting the ability of a group to organize for collective action, such as small group size and lower costs of communication. Several scholars have extended the theory of collective action to explicitly model the role of lobbying activities, lobby-group organization structures and processes, and political entrepreneurs in shaping political outcomes (Becker, 1983, Moe, 1980).

Several examples challenge collective action theories' ability to explain protectionism. For example, farmers represented a large proportion of the US labor force when they first received substantial subsidies in the 1930s. Argentina and Canada both have highly urbanized economies with similar agro-climatic conditions, but have diametrically opposed farm policies. In order to explain these discrepancies, several authors have looked to per-capita incomes along with lobby groups to explain protectionism. According to these arguments, the richer the 
country and the fewer the farmers, the lower the organizational costs and free-riding activities. Gardner (1987) finds empirical support for these factors in explaining US farm policy, and Bates (1987) for African agricultural policies. Another puzzling observation that limits the utility of collective action theory is the different regulatory preferences between the United Kingdom (UK) and Germany. Both countries are rich but have different agricultural policies. The UK preferred lower prices and Germany higher prices in the formulation of the European Common Agricultural Policy (CAP). De Gorter and Tsur (1991) explain these differences by pointing to farm numbers, farm size, farm size distribution, and per-capita benefits to farmers, consumers, and taxpayers.

The second category of research concerns the literature explaining farm policy. Several models in the tradition of Downs (1957) address the interaction between politicians and their citizens. Bates (1990) argues that politicians are entrepreneurs who maximize total political support and competition between politicians ensures that a decrease in relative farm (prepolicy) income induces politicians to compensate farmers. The relative income hypothesis explains why agriculture receives support in industrialized countries (Inhwan, 2008) and the correlation between farm protection and productivity (Honma and Hayami, 1986). Intervention to assist farmers occurs when economic conditions hurt agriculture; commodity protection is inversely related to changes in the world market price of the commodity and positively related to the economic size of the commodity sector (de Gorter and Swinnen, 1995, Swinnen et al., 2000). In other words, when economic conditions turn against agriculture, governments are more likely to protect farmers, and more so when their vested interest is large.

The third category of research is a revealed preference approach that combines the perspectives of collective action and the politician-voter models. Revealed preference models 
include both lobby group activities and a politician objective function (Zusman, 1976, Grossman and Helpman 1994). For example, in Grossman and Helpman (1994) interest groups make political contributions in order to influence an incumbent government's choice of trade policy. The interest groups bid for protection with their campaign support, and politicians maximize their own welfare, which depends on total contributions collected from interest groups and on the welfare of the voters. Lobby groups, in some cases, prefer to have the government use protectionist trade policy-rather than more efficient means - to transfer income.

The final category of research on agricultural protectionism consists of studies that investigate the influence of political and institutional variables. Institutional factors may affect both the 'influence action' of Becker's (1983) lobby group model and the 'support function' of the politician-voter models. Geographic representation and federalism may allow farmers concentrated in one area to exert disproportionate political influence on multiple levels of government (Peterson, 1995).

Several studies have examined the relationship between legislative votes by U.S. politicians and political action committee (PAC) contributions made to politicians by agricultural lobby groups. A politician's voting behavior and the level of contributions both affect a politician's re-election chances. The literature is mixed in terms of how strongly PAC monies affect individuals' votes. Chappell (1982) finds little impact of PAC monies on congressional voting, while other researchers find a statistically significant influence of PAC monies on agricultural (de Gorter, 1983, de Gorter and Rausser, 1989). During an election year, government incumbents could issue policies to foster their chances to get re-elected, and much of the literature on the political economy of protectionism has suggested that representatives 
will distribute protection to groups while seeking election (Grossman and Helpman, 1994, Magee et al., 1989).

A few studies investigate the impact of political variables on agricultural protectionism. Beghin and Kherallah (1994) and Olper (2001) find mixed results on the effect of institutional factors on agricultural protectionism, with multi-party systems and democracies being more protectionist. Thies and Porche (2007) examine the extent of party fragmentation within the legislature and find that party fragmentation and agricultural protectionism are positively correlated; greater fragmentation may force parties to succumb to pressure groups (Thies and Porche, 2007, Nielson, 2003). Davis (2003) supports this contention in a study of agricultural trade liberalization negotiations between the US, EU, and Japan. Thies and Porche (2007) found a positive impact of federalism on protectionism.

Considering the research surveyed above, we contend that government officials subject to the demands of lobby-groups may respond by legislating and implementing protectionist policies under cover of protecting their citizens and food supply from food-borne illness, disease, etc. With WTO member governments deterred from implementing more transparent forms of trade protectionism (i.e., tariffs, import quotas, exchange rate restrictions) by multilateral trade rules, lobbyist-group activity by agricultural interests may be directed toward acquiring non-tariff barrier forms of protectionism (Kono, 2006). Reduced levels of protectionism, for example lower tariff rates, is similar to the worsening of economic conditions that scholars argue is more likely to result in protectionism in the literature on farm policy mentioned above. Thus, governments under pressure from multilateral trade institutions and trade partners to eliminate protectionism in agricultural trade (Messerlin 2005), SPS regulations seem a likely target of agricultural groups seeking protection from imported food. Thus, we 
hypothesize the following with respect to the relationship between existing, transparent forms of agricultural protectionism:

Hypothesis 1: As the relative rate of assistance to tradable agriculture increases, the number of SPS notifications issued in a given year will decrease, ceteris paribus.

In addition to the inverse relationship between direct measures of agricultural protectionism and SPS notifications, there may also be an indirect relationship between the level of demand for agricultural protectionism by producer groups and SPS regulatory activity. As a result, we also hypothesize:

Hypothesis 2: As agricultural productivity increases, the number of SPS notifications issued in a given year will decrease, ceteris paribus.

Hypothesis 3: As agricultural employment increases, the number of SPS notifications issued in a given year will decrease, ceteris paribus.

In the next section, we describe the data and statistical estimation used to test these hypotheses.

\section{RESEARCH DESIGN}

\section{a. Dependent variable}

The WTO presently boasts 157 member governments (World Trade Organization, 2008), and we examine the SPS regulatory-notification activity of members between the years 1996 and 2005. The unit of analysis for statistical estimation is the country-year. ${ }^{3}$ To check the

\footnotetext{
${ }^{3}$ Appendix A lists the countries in the estimated sample for Model 1. Data limitations reduce our number of observations from the potential 1530 for two reasons. First, the measures we employ to test our hypotheses and control for other important factors related to SPS notification activity (see below) are unavailable for WTO members in all years. Second, data for European countries are averaged after the point at which they entered the
} 
robustness of the results, we also estimate the models using samples of only developed and developing countries. Each country's classification is determined by WTO development status classification, with high income countries classified as developed. SPS notification is the dependent variable and measures the total number of notifications submitted to the WTO by a member country in a given year. ${ }^{4}$ Under the transparency provision of the SPS Agreement, codified in the SPS Agreement's 'Annex B: Transparency of Sanitary and Phytosanitary Regulations,' governments should keep their trading partners informed of any measures adopted to protect human, animal, or plant health (WTO, 1998a, p. 44-47). Whenever a government is proposing a new or modified SPS regulation that may affect trade, the government should notify the WTO SPS Secretariat, who then circulates the notification to other WTO member governments. Governments are required to submit the notification in advance of the implementation of a proposed new regulation to provide trading partners an opportunity to comment. SPS notifications are archived electronically in the SPS Information Management System (SPS-IMS) of the WTO (WTO, 2008b).

\section{b. Independent variables}

EU. Measures for fifteen EU countries are averaged between the years 1996-2003. After ten additional countries joined the EU in 2004, the data of the 25 members are averaged for the years 2004-2005.

${ }^{4}$ Each notification may include multiple changes to individual regulations. To the extent that our count of notifications differs from the number of regulatory changes a government implements, it will introduce random measurement error into our dependent variable and make coefficient estimates less efficient. Thus, if we find statistically significant relationships using notifications as a dependent variable, we can infer that the standard errors of the coefficients would decrease, improving the statistical significance of our independent (Berry, 1993). 
This study incorporates two variables measuring the overall level of agricultural protectionism. The first variable is the Relative Rate of Assistance (RRA) to tradable agriculture. This measure captures the level of assistance provided to tradable agricultural production relative to non-agricultural production in a given year through government policy such as tariffs, subsidies, or exchange rate manipulation (Anderson, 2009a, Anderson 2009b). Measured in percentage terms, the RRA is larger as a government's policy exhibits a greater pro-agricultural bias. The data is available from the World Bank and is a new measure of agricultural price distortions. The second variable is the average producer nominal Protection Coefficient (PC) across all available commodity categories. This measure is the ratio between the average price producers receive at the farm gate (including payments tied to output) and the border price (OECD, 2004b, Thies and Porche, 2007). Data are available from the Organisation for Economic Co-operation and Development (OECD) (OECD, 2008). The PC is a standard measure of agricultural protectionism utilized by other studies (Beghin and Kherallah, 1994, Honma and Hayami, 1986, Inhwan, 2008, Thies and Porche, 2007). Because the NPC is available for only OECD countries, including it in the model reduces the sample size; we emphasize the RRA measure in our presentation.

The analysis also incorporates two variables measuring the potential level of demand for protectionism by agricultural producers. We measure agricultural employment as a proxy for the size of agricultural producer groups. This variable is measured as the logarithm of agricultural labor as a percentage of the total labor force and is obtained from the World Development Indicators (WDI, 2007). An agricultural productivity ratio is used to measure the comparative advantage of agriculture in a country. It is measured as the logarithm of the ratio of labor productivity in agriculture to overall productivity in the economy, both in real terms. 
Inter-country cross-section data on labor productivity in agriculture, as measured by total agricultural output per male worker, is available from the International Labour Organization (ILO) (KILM, 2007). As agricultural employment and productivity increase, the demand for protectionism should decrease, so the coefficients for these variables should be negative.

Two political-institutional variables are included in the models. These variables represent the ease with which policymakers can supply agricultural protectionism. The first variable is a measure of federalism; a dichotomous variable scored one if state or provincial governments are locally elected, and otherwise scored zero. The second variable measures party fragmentation in the legislature using the logarithm of the probability that two members picked randomly from the legislature will be of different parties. The data are taken from the 'Database of Political Institutions' of the World Bank (DPI, 2006, Beck et al., 2001).

Consumer awareness of food safety (and, perhaps, animal and plant health) plays a role in determining the levels of SPS regulations in a country (Ganiere and Chern, 2004, Ewen et al., 2006, Umali-Deininger and Sur, 2007, Wang et al., 2008). We substitute the literacy rate as a proxy for consumer awareness. We anticipate that greater consumer awareness will increase the number of food safety, animal health, and plant health regulations, and thus the number of SPS notifications of these regulations. The literacy rate is measured as the percentage of people age 15 and above who can read and write a short simple statement on their everyday life. Data are obtained from the World Bank's 'World Development Indicators' (WDI, 2007).

While consumer awareness of food safety issues will drive demand for greater regulation of the food supply, not all countries are equally equipped to implement regulations. Institutionally robust governments may very well intervene to regulate a country's food safety, animal health, or plant health; however, institutional deficiencies may negatively impact 
national SPS regulatory activity (Josling et al., 2004). This study captures institutional capacity with an index that is the average of six variables used to measure institutional development; larger values indicate greater institutional capacity (Kaufmann et al., 1999). The data come from the 'World Governance Indicators' (WGI) of the World Bank; the following definitions, provided by the WGI website (WGI, 2008), are explanatory:

1. Voice and Accountability measures the extent to which country's citizens are able to participate in selecting their government, as well as freedom of expression, freedom of association, and a free media.

2. Political Stability and Absence of Violence/Terrorism measures the perceptions of the likelihood that the government will be destabilized or overthrown by unconstitutional or violent means, including domestic violence and terrorism.

3. Government Effectiveness measures the quality of public services, the quality of the civil service and the degree of its independence from political pressures, the quality of policy formulation and implementation, and the credibility of the government's commitment to such policies.

4. Regulatory Quality measures the ability of the government to formulate and implement sound policies and regulations that permit and promote private sector development.

5. Rule of Law measures the extent to which agents have confidence in and abide by the rules of society, in particular the quality of contract enforcement, the police, and the courts, as well as the likelihood of crime and violence.

6. Control of Corruption measures the extent to which public power is exercised for private gain, including petty and grand forms of corruption, as well as 'capture' of the state by elites and private interests (WGI, 2008). 
The WTO's SPS Committee has noted that members are progressively, and in a more comprehensive manner, meeting their notification obligations (WTO, 1999). Figures 1 and 2 display the total SPS notifications and the average number of SPS notifications per country.

\section{*** Figures 1 and 2 here ***}

Both figures demonstrate evidence for such growth in SPS notification activity. Between January 1995 and January 2000, 969 SPS notifications were submitted, and between January 2000 and January 2005, 2971 SPS notifications were submitted; this represents an increase of 206.6 per cent (WTO, 2008b). Developing countries are also increasing their SPS notification activity. Between January 2003 and June 2004, developing countries issued a total of 452 SPS notifications (Cash et al., 2004, WTO, 2008b). Between January 2005 and June 2006, developing countries issued a total of 522 notifications, an increase of 15.5 per cent (WTO, 2008b). To account for such increases in SPS notification activity, we include a time trend variable recording the year of each observation.

\section{c. Statistical estimation}

The dependent variable-SPS notifications-is a count of the number of notifications submitted by countries in a given year. Therefore, standard regression techniques such as ordinary least squares (OLS) are inappropriate and will lead to biased, inconsistent, and inefficient estimates (Long, 1997). In addition, through investigation we can reject the null hypothesis of no over-dispersion in the dependent variable. ${ }^{5}$ We estimate negative binomial regressions to model our count dependent variable and report robust standard errors.

\section{EMPIRICAL ANALYSIS AND DISCUSSION}

\footnotetext{
${ }^{5}$ We also estimated zero-inflated negative binomial regression models and found that we could not reject the null hypothesis in a Vuong test for Model 1 in Table 1. Thus, the negative binomial distribution is appropriate.
} 
Tables 1 and 2 present four statistical models of the determinants of SPS notifications. Model 1 in Table 1 includes the RRA measure of agricultural protectionism while Model 2 utilizes the PC measure. In Table 2, Models 3 and 4 present the data for developed and developing countries, respectively, with the RRA measure of protectionism.

In general, the results support Hypotheses 1 and 2, but not Hypothesis 3. Both the RRA and PC coefficients are negative and statistically significant. The agricultural productivity coefficient is statistically significant and negative in all models, while the ratio of agricultural employment coefficient is only significant with the expected sign (negative) for developed countries (Model 3). The control variables are largely consistent with the expectations of the literature on agricultural protectionism and the time trend is positive and significant in all four models. Each model overall is statistically significant, as shown by the chi-square value.

****Tables 1 and 2 Here****

Specifically, our key measure of agricultural protectionism, the Relative Rate of Assistance to tradeable agriculture, is negative and statistically significant. Higher levels of assistance to producers of agricultural trade in a country are associated with fewer SPS notifications, as we predict with Hypothesis 1. In Table 2, the same relationship holds for developing and developed countries in Models 3 and 4, respectively, giving us confidence that our findings are not solely a product of developed country governments' ability and desire to protect consumers' health. Our alternative measure of agricultural protectionism, the Protection Coefficient, is also negatively correlated (and statistically significant) with SPS notifications by an OECD government.

Figure 3 illustrates the substantive relationship of agricultural protectionism and the probability of a particular count of notifications. Three lines, with confidence intervals depicted 
by the shaded areas surrounding them, are displayed. The figure demonstrates that moving from the lowest value of the RRA measure to its highest value increases the probability that a country will submit zero SPS notifications. The probability that a country does not notify the WTO of an SPS regulatory change increases from .09 to .55. In other words, the government that assists its agricultural sector the most in our data is five times more likely to refrain from changing its SPS regulations compared to the government that assists agriculture the least. The effect of the RRA measure is also positive for the probability of at least one SPS notification, but no discernable influence appears for the probability of eight SPS notifications (the average number of predicted notifications). Overall, the data in our sample allows us to reasonably conclude that the RRA to tradeable agriculture is mostly related to whether governments engage in any SPS notification activity at all. We interpret this to mean that governments supporting agricultural producers through traditional trade policies are unlikely to resort to (potential) non-tariff barriers like SPS regulations.

$* * * *$ Figure 3 here $* * * *$

Our measures of demand for protectionism by agricultural interest groups show contrasting results that support Hypothesis 2, but not Hypothesis 3. The coefficients for the agricultural-productivity variables are all correlated (negatively) with the number of SPS notifications submitted to the WTO. In cases where agriculture has a comparative advantage, a country engages in less (on average) SPS notification activity. In other words, when farmers realize that they are at a disadvantage compared to other sectors, they increasingly lobby their government for additional SPS regulations. This result is consistent with research by others showing that as the comparative advantage of agriculture decreases, producers are more likely to receive support (Beghin and Kherallah, 1994, Honma and Hayami, 1986, Thies and Porche, 
2007). With respect to the agricultural-employment variable, the results show that when a greater proportion of a country's population is employed in agriculture the country engages in less food safety and animal and plant health regulatory activity, but only among developed countries (Model 3). Collective action theories draw some support from these findings, as agriculturally based economies (in terms of labor and employment) find it more difficult to succeed in securing protection through SPS measures. This suggests that when agricultural groups are smaller in size, they can lobby the government more effectively for additional SPS regulations to protect their sectors against foreign competition.

Party fragmentation appears to reduce the number of SPS notifications for developed countries, but not for developing countries. A more fragmented party system reduces the chances that new or modified SPS regulations will be adopted. Although Thies and Porche (2007) find robust evidence that centralized control in the legislature under fewer parties reduces the level of direct producer support, this study finds that more fragmented party systems result in fewer SPS measures that will affect trade. The results suggest that party fragmentation does not lead to issuing food safety and animal and plant health regulations. Another political-institutional variable, federalism, is positive in all four models, and statistically significant in Models 1-3. Federal systems issue a larger number of SPS notifications, but only in developed countries.

The institutional-capacity index variable is positive (and significant) in all four models. ${ }^{6}$ A government's institutional capacity, or the resources and capability to develop and

\footnotetext{
${ }^{6}$ As alternative measures of governments' capacity to implement regulatory food safety and animal and plant health policies we estimate models substituting the institutional capacity index with the polity scale measuring democratic regime characteristics from the Polity IV project (Marshall, Gurr and Jaggers 2009). We also substitute the natural log of Gross Domestic Product (in constant US dollars). In both cases, the results remain identical for all of the other variables included in Model 1, Table 1.
} 
implement SPS regulations, has a positive influence on its tendency to implement SPS regulations. National agri-food regulatory institutions have characteristics that reflect the political circumstances and other factors specific to a country and appear to make a difference in regulation of food safety and animal and plant health (Josling et al., 2004). The literacy-rate variable, a proxy for consumer awareness, is positive and significant in three of the four models. An increase in consumer awareness is correlated with an increase in the number of SPS notifications issued by governments. The literacy rate is also positive-but not significant-in Model 2, which is likely because OECD countries (the sample is restricted to OECD countries by the PC measure) have little variation in their literacy rates. In the next section, we present the conclusions of our research.

\section{CONCLUSION}

In some instances, SPS regulations can lead to policies that unduly restrict international agricultural and food trade. Proposals submitted by different countries to bring further discipline to SPS regulatory activity both before and after the Doha Round of Multilateral Trade Negotiations reflect this concern-especially among developing countries (Kastner et al., 2005). Developing countries have signaled frustration with the stringency of standards imposed by developed countries on food and agricultural products. On the other hand, developed countries have argued that the adequacy of WTO rules is in question with the emergence of novel production technologies, new disease outbreaks, and fresh demands for regulations from concerned consumers.

Our research investigates whether or not the stringency of food safety, animal health, and plant health regulations (collectively measured using SPS notifications) correlates with 
agricultural protectionism or potential demand for protection by agricultural groups. The empirical evidence shows that WTO members may be substituting SPS rules for traditional forms (i.e. tariffs, subsidies, etc.) of agricultural protectionism. Even controlling for both consumer awareness and a government's institutional capacity, SPS regulations are more likely to be altered when agricultural protectionism is lower and when the demand for protectionism by agricultural groups increases. The pattern observed in our data is that regulatory barriers on agricultural trade may also be protectionist policies substituted for more transparent trade restrictions (Kono 2006).

The SPS Agreement affirms the sovereign right of countries to decide what their ALOPS and SPS regulations will be, provided they are based on risk assessment and consistently applied. Our research suggests that we cannot claim that SPS regulations are solely issued for consumer protection and risk-based reasons. Several cases, cited in this paper, have shown that food safety regulations could be discriminatory and unduly trade-distorting. Governments may increase the stringency of their food safety regulations for protectionist purposes. While many countries do adjust to newly issued SPS regulations adopted by their importing trade partners, others lament these new trade-restricting SPS regulations, lodging complaints with the WTO SPS Committee and the WTO Dispute Settlement Body (Messerlin 2005) and raising concerns about potential international economic conflict (Lutz and Lutz 2009) .

Thus, our research builds upon the qualitative studies investigating the legitimacy of individual restrictions on food trade by assessing the more general relationship between agricultural protectionism and SPS regulations. Though specific determinations of such legitimacy may be difficult, this study-a novel examination of whether SPS regulations may be 
connected to agricultural protectionism - has established a solid foundation for future studies on the role SPS regulations play in the world economy. 
FIGURES AND TABLES

Figure 1: Number of SPS Notifications

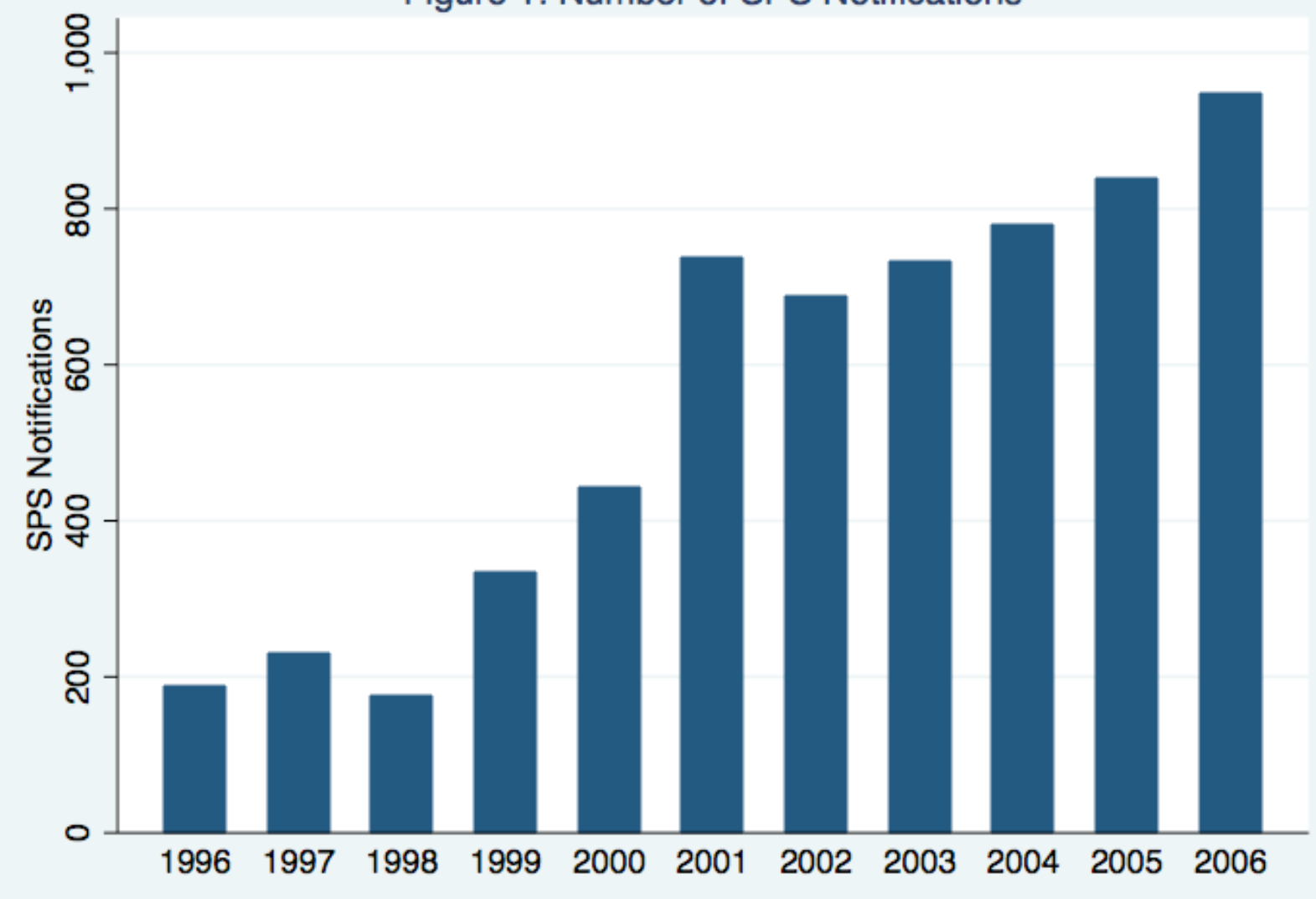


Figure 2: Average SPS Notifications Per Country

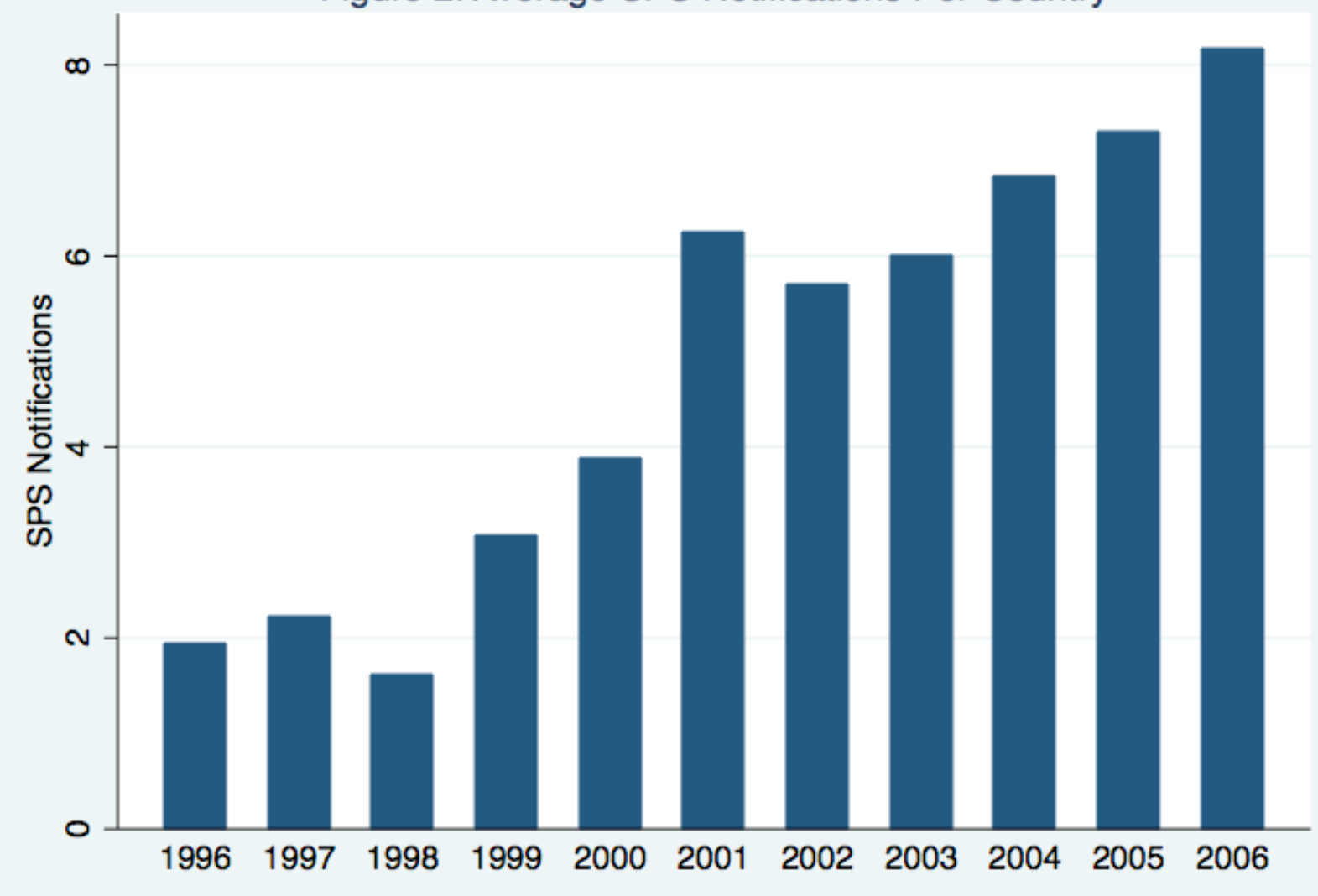


Figure 3: Agricultural Protectionism and SPS Notifications

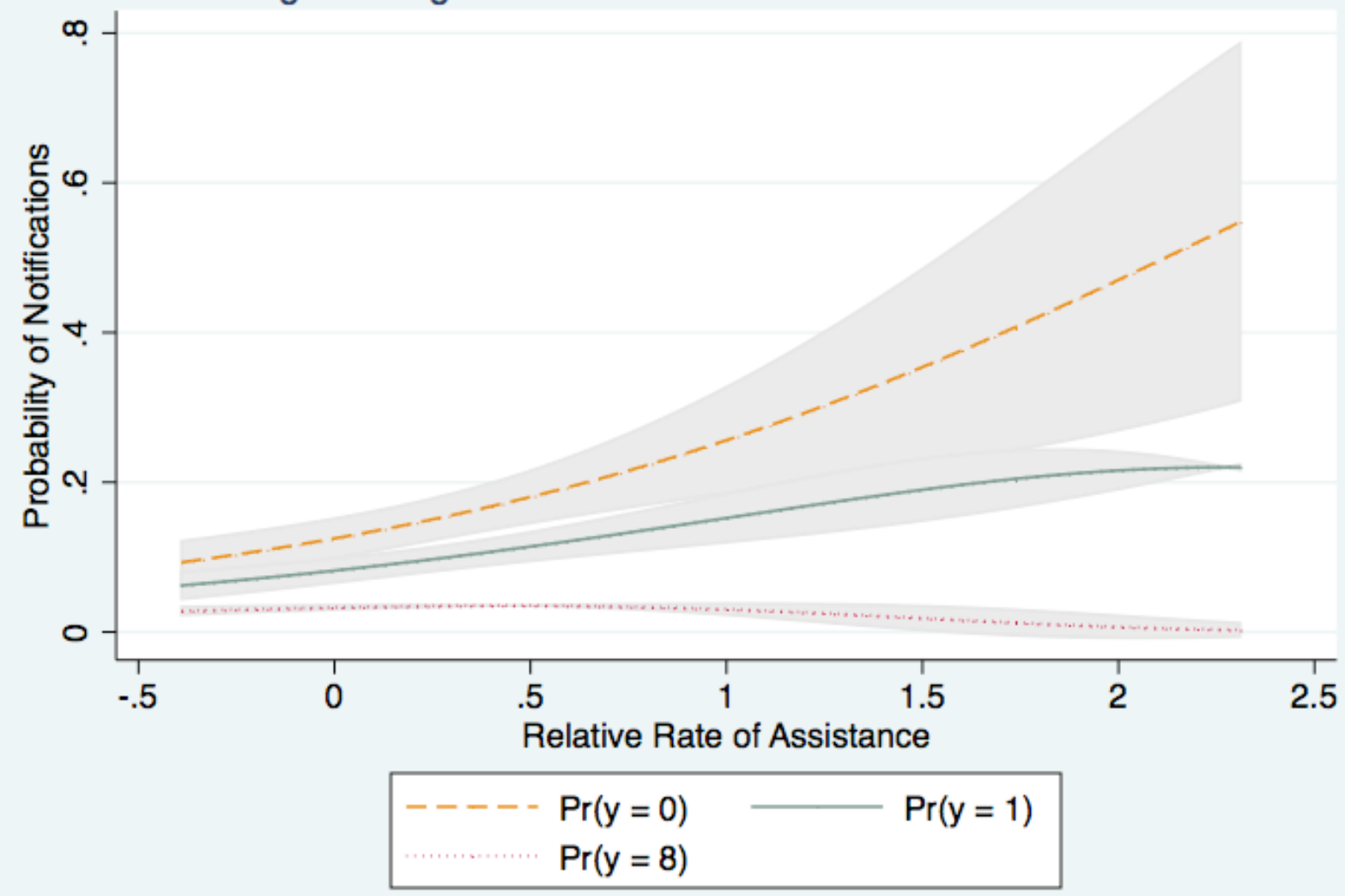


Table 1: Determinants of SPS notifications, 1996-2005

\begin{tabular}{|c|c|c|c|c|}
\hline \multirow[t]{2}{*}{ Independent Variables } & \multicolumn{2}{|c|}{ Model 1} & \multicolumn{2}{|c|}{ Model 2} \\
\hline & Coefficient & SE & Coefficient & SE \\
\hline Relative Rate of Assistance & -1.13 & $.264^{* *}$ & & \\
\hline Protection Coefficient & & & -1.29 & $.235^{* *}$ \\
\hline Agricultural Employment & -.021 & .141 & -.322 & .255 \\
\hline Agricultural Productivity & -.329 & $.198 * *$ & -.451 & $.167^{* *}$ \\
\hline Federalism & .814 & $.274^{* *}$ & 1.48 & $.365^{* *}$ \\
\hline Party Fragmentation & -2.05 & $.669 * *$ & -4.70 & $1.05^{* *}$ \\
\hline Institutional Capacity & .390 & $.183^{* *}$ & .646 & $.286^{* *}$ \\
\hline Consumer Awareness & .129 & $.045^{* *}$ & -.048 & .070 \\
\hline Time Trend & .156 & $.034^{* *}$ & .113 & $.032 * *$ \\
\hline Constant & -321.85 & $68.10 * *$ & -215.92 & $66.46 * *$ \\
\hline $\mathrm{N}$ & \multicolumn{2}{|c|}{231} & \multicolumn{2}{|c|}{144} \\
\hline Wald $\chi^{2}$ & \multicolumn{2}{|c|}{$107.84(.000)$} & \multicolumn{2}{|c|}{$150.46(.000)$} \\
\hline
\end{tabular}


Table 2: Determinants of SPS notifications by Development Classification, 1996-2005

\begin{tabular}{|c|c|c|c|c|}
\hline \multirow[t]{2}{*}{ Independent Variables } & \multicolumn{2}{|c|}{ Model 3: Developed Countries } & \multicolumn{2}{|c|}{ Model 4: Developing Countries } \\
\hline & Coefficient & SE & Coefficient & SE \\
\hline Relative Rate of Assistance & -1.70 & $.350 * *$ & -.686 & $.366^{* *}$ \\
\hline Agricultural Employment & -.508 & $.322 *$ & .198 & .185 \\
\hline Agricultural Productivity & -.569 & $.199 * *$ & -.470 & $.345^{*}$ \\
\hline Federalism & 1.07 & $.417^{* *}$ & 1.24 & .392 \\
\hline Party Fragmentation & -6.82 & $1.69 * *$ & -.516 & .687 \\
\hline Institutional Capacity & 1.01 & $.339 * *$ & .621 & $.180 * *$ \\
\hline Consumer Awareness & .393 & $.140 * *$ & .203 & $.063 * *$ \\
\hline Time Trend & .126 & $.038 * *$ & .103 & $.048 * *$ \\
\hline Constant & -284.58 & $78.75^{* *}$ & -222.98 & $94.53^{* *}$ \\
\hline $\mathrm{N}$ & \multicolumn{2}{|c|}{110} & \multicolumn{2}{|c|}{121} \\
\hline Wald $\chi^{2}$ & \multicolumn{2}{|c|}{$250.83(.000)$} & \multicolumn{2}{|c|}{$43.71(.000)$} \\
\hline
\end{tabular}

Note: Coefficients and robust standard errors from negative binomial regression estimation. ${ }^{*} \mathrm{p}<.10, * * \mathrm{p}<.05$ 
ApPendix A: LIST OF CoUntries

ARGENTINA
AUSTRALIA
BANGLADESH
BRAZIL
BULGARIA
CANADA
CHILE
CHINA
COLOMBIA
COLOMBIA
CZECH REPUBLIC
DOMINICAN REPUBLIC
EGYPT
EUROPEAN UNION
GHANA
HUNGARY
INDONESIA
JAPAN
LITHUANIA
MADAGASCAR
MALAYSIA
MEXICO
NEW ZEALAND
NORWAY
PAKISTAN
PHILIPPINES
POLAND
REPUBLIC OF KOREA
SLOVAK REPUBLIC
SOUTH AFRICA
SRI LANKA
SWITZERLAND
TANZANIA
THAILAND
UNITED STATES
M




\section{REFERENCES}

Alston L. J. and Hatton T. J. (1991), 'The Earnings Gap Between Agricultural and Manufacturing Laborers, 1925-1941', Journal of Economic History, 51, 83-100.

Anderson K. (2009a), 'Five Decades of Distortions to Agricultural Incentives', in K. Anderson (ed.), Distortions to Agricultural Incentives: A Global Perspective, 1955-2007, Washington, D.C.: The World Bank and Palgrave Macmillan.

Anderson K. (2009b), 'Distortions to Agricultural Versus Nonagricultural Producer Incentives,' Annual Review of Resource Economics, 1: 55-74.

Bates R. H. (1987), Essays on the Political Economy of Rural Africa, (University of California Press, Berkeley, California).

Bates R. H. (1990), 'The Political Framework for Agricultural Policy Decisions', in C. Eichner and J. Staatz (eds.), Agricultural Development in the Third World, (Baltimore, Maryland: Johns Hopkins University Press), 154-59.

Beck T., Clark G., Groff A., Keefer P. and Walsh P. (2001), 'New tools in comparative political economy: the database of political institutions', World Bank Economic Review, 15, 1, 165-76.

Becker G. (1983), 'A theory of competition among pressure groups for political influence', Quarterly Journal of Economics, 98, 371-400.

Beghin J. and Kherallah M. (1994), 'Political institutions and international patterns of agricultural protection', Review of Economics and Statistics, 76, 3, 482-89.

Berry W.D. (1993), Understanding Regression Assumptions, (Sage Publications, London, UK). 
Brown C., Lynch L. and Zilberman D. (2002), 'The economics of controlling insect-transmitted diseases', American Journal of Agricultural Economics, 84, 2, 279-91.

Calvin L. and Krissoff B. (1998), 'Technical barriers to trade: a case study of phytosanitary barriers and US-Japanese apple trade', Journal of Agricultural and Resource Economics, 23, 2, 352-66.

Cash J., Kastner J., Anders B., Timmons S. and Helou E. (2004), 'SPS Notifications Tool', http://frontier.k-state.edu).

Chappell H. W. (1982), 'Campaign contributions and Congressional voting: a simultaneous Probit-Tobit Model', Review of Economics and Statistics, 64, 77-83.

Darby M. R. and Karni E. (1973), 'Free competition and the optimal amount of fraud', Journal of Law and Economics, 16, 1, 67-68.

Davis C. L. (2003), Food Fights Over Free Trade: How International Institutions Promote Agricultural Trade Liberalization, (Princeton University Press, Princeton, New Jersey).

de Gorter H. (1983), 'Agricultural Policies: A Study in Political Economy', PhD thesis, University of California-Berkeley).

de Gorter H. and Rausser G. C. (1989), 'Endogenizing U.S. milk price supports', CUDARE Working Paper Series 504, (Berkeley, California: University of California at Berkeley, Department of Agricultural and Resource Economics and Policy).

de Gorter H. and Swinnen J. (1995), 'The economic polity of farm policy: reply', Journal of Agricultural and Resource Economics, 46, 403-14. 
de Gorter H. and Swinnen J. (2002), 'Political Economy of Agricultural Policy', in B. L. Gardner and G. C. Rausser (eds.), Handbook of Agricultural Economics (Volume 2B: Agricultural and Food Policy), (Amsterdam: Elsevier).

de Gorter H. and Tsur Y. (1991), 'Explaining price policy bias in agriculture: the calculus of support-maximizing politicians', American Journal of Agricultural Economics, 72, 131-37.

Downs A. (1957), An Economic Theory of Democracy, (Harper and Row, New York).

DPI (2006), 'Database of Political Institutions', World Bank).

Ewen C., Todd D. and Narrod C. (2006), 'Understanding the links between agriculture and health, food safety, and food borne diseases', 2020 Vision for Food, Agriculture, and the Environment, (Washington, DC: International Food Policy Research Institute), Focus 10, Brief 5.

Ganiere P. and Chern W. S. (2004), 'Consumer acceptance of genetically modified foods: a profile of American consumers', Annual Meeting of the American Agricultural Economics Association, (Denver, Colorado.

Gardner B. L. (1987), 'Causes of US farm commodity programs', Journal of Political Economy, 95, 290-310.

Gignilliat J. L. (1961), 'Pigs, Politics, and Protection: The European Boycott of American Pork, 1879-1891', Agricultural History, 35, 3-12.

Grossman G. and Helpman E. (1994), 'Protection for sale', American Economic Review, 84, 4, 833-50. 
Henson S. J., Loader R. J., Swinbank A., Bredahl M. and Lux N. (2003), 'The impact of sanitary and phytosanitary measures on developing countries', Working paper, University of Reading).

Honma M. and Hayami Y. (1986), 'Structure of agricultural protection in industrial countries', Journal of International Economics, 20, 1-2, 115-29.

Inhwan, Jin (2008), 'Determinants of Agricultural Protection in Industrial Countries: An Empirical Investigation', Economics Bulletin, 17, 1, 1-11.

James S. and Anderson K. (1998), 'On the Need for More Economic Assessment of Quarantine/SPS Policies', Australian Journal of Agricultural and Resource Economics, 42, 4, 525-44.

Josling T., Roberts D. and Orden D. (2004), 'Food Regulation and Trade', (Washington, DC: Institute for International Economics).

Kastner J., Ackleson J. and Cash J. (2005), 'Doha and Development', Commentary from Frontier, http://frontier.kstate.edu/ResearchAndAnalysis/Commentary/KastnerAckleson20051216.pdf.

Kastner J. and Powell D. (2002), 'The SPS Agreement: Addressing historical factors in trade dispute resolution', Agriculture and Human Values, 19, 4, 283-92.

Kaufmann D., Kraay A. and Zoido-Lobaton P. (1999), 'Aggregating Governance Indicators', Working Paper No. 2195, World Bank).

KILM (2007), Key Indicators of the Labor Market, (International Labor Organization, Geneva, Switzerland). 
Kimenju S. C. and de Groote H. (2008), 'Consumer willingness to pay for genetically modified food in Kenya', Agricultural Economics, 38, 35-46.

Kono, D. Y. (2006), 'Optimal Obfuscation: Democracy and Trade Policy Transparency', American Political Science Review, 100, 3, 369-384.

Long J. S. (1997), Regression Models for Categorical and Limited Dependent Variables, (Sage Publications, London).

Lutz, B. J. and J. M. Lutz. (2009), "Factory Farming and Potential Problems in International Trade," Global Economy Journal. 9(3).

Marshall, M., Gurr, T. R. and Jaggers, K. (2009), 'POLITY'M IV PROJECT: Political Regime Characteristics and Transitions, 1800-2009', Dataset Users' Manual, Center for Systemic Peace, http://www.systemicpeace.org/polity/polity4.htm

Magee S. P., Brock W. A. and Young L. (1989), Black Hole Tariffs and Endogenous Policy Theory: Political Economy in General Equilibrium, (Cambridge University Press, Cambridge).

Messerlin, Patrick. (2005), "Agricultural liberalization in the Doha Round," Global Economy Journal 5(4).

Moe T. M. (1980), The Organization of Interests: Incentives and the Internal Dynamics of Political Interest Groups, (University of Chicago Press, Chicago, Illinois).

Moy G. G. (1999), 'Food Safety and Globalization of Trade: A Challenge to the Public Health Sector', World Food Regulation Review, 8, 9, 21.

Nielson D. L. (2003), 'Supplying trade reform: political institutions and liberalization in middleincome presidential democracies', American Journal of Political Science, 47, 3, 470-91. 
OECD (1997), Regulatory Reform in the Agro-Food Sector (Regulatory Reform Volume I: Sectoral Studies), (OECD, Paris).

OECD (2004a), The Impact of Regulations on Agro-Food Trade: The Technical Barriers to Trade (TBT) and Sanitary and Phytosanitary (SPS) Agreements, (OECD, Paris).

OECD (2004b), OECD Agriculture Policies: at a glance, (OECD, Paris).

OECD (2008), 'Producer and Consumer Support Estimates (http://stats.oecd.org/wbos/Index.aspx?usercontext=sourceoecd)', $\quad$ (Paris: $\quad$ OECD Statistics).

Olper A. (2001), 'Determinants of agricultural protection: the role of democracy and institutional setting', Journal of Agricultural Economics, 52, 2, 75-92.

Olson M. (1965), The Logical of Collective Action: Public Goods and the Theory of Groups, (Harvard University Press, Cambridge, Massachusetts).

Olson M. (1985), 'Space, agriculture, and organization', American Journal of Agricultural Economics, 67, 928-37.

Olson M. (1990), 'Agricultural exploitation and subsidization: there is an explanation', Choices, 4, 8-11.

Orden D., Narrod C. and Glauber J. W. (2001), 'Least trade-restrictive SPS policies: an analytical framework is there but questions remain', in K. Anderson, C. McRaye and D. Wilson (eds.), The Economics of Quarantine and the SPS Agreement, (Adelaide and Canberra, Australia: Center for International Economic Studies and AFFA, Biosecurity). 
Otsuki J., Wilson J. and Sewadeh M. (2000), 'Saving Two in a Billion: A Case Study to Quantify the Trade Effect of European Food Safety Standards on African Exports', Working Paper, World Bank).

Otsuki J., Wilson J. S. and Swadeh M. (2001), 'Saving two in a billion: quantifying the trade effect of European food safety standards on African exports', Food Policy, 26, 495-514.

Peterson P. (1995), The Price of Federalism, (Brookings, Washington, D.C.).

Snape R. and Orden D. (2001), 'Integrating import risk analysis and trade benefit analysis', in K. Anderson, C. McRaye and D. Wilson (eds.), The Economics of Quarantine and the SPS Agreement, (Adelaide and Canberra, Australia: Center for International Economic Studies and AFFA, Biosecurity).

Snyder L. L. (1945), 'The American-German Pork Dispute, 1879-1891', Journal of Modern History, 17, 16-28.

Stern, R. M. (2005), "Overview: Perspectives on the WTO Doha Development Agenda Multilateral Trade Negotiations," Global Economy Journal 5(4).

Swinnen J., de Gorter H., Rausser G. and Barnerjee A. (2000), 'The political economy of public research investment and commodity policies in agriculture: an empirical study', Agricultural Economics, 22, 111-22.

Thies C. and Porche S. (2007), 'The political economy of agricultural protection', Journal of Politics, 69, 1, 116-27.

Umali-Deininger D. and Sur M. (2007), 'Food safety in a globalizing world: opportunities and challenges for India', Agricultural Economics, 37, 1, 135-47. 
Vogel D. (1995), Trading Up: Consumer and Environmental Regulation in a Global Economy, (Harvard University Press, Cambridge, Massachusetts).

Wang Z. G., Mao Y. and Gale F. (2008), 'Chinese consumer demand for food safety attributes in milk products', Food Policy, 33, 1, 27-36.

WDI (2007), 'World Development Indicators', CD-ROM, World Bank).

WGI (2008), 'World Governance Indicators, http://info.worldbank.org/governance/wgi/index.asp', World Bank).

World Trade Organization (2012), 'Members and Observers, http://www.wto.int/english/thewto e/whatis e/tif e/org6 e.htm'. Accessed Dec. 2012.

WTO (1998a), 'Agreement on the Application of Sanitary and Phytosanitary Measures', in WTO (ed.), The WTO Agreement Series: Sanitary and Phytosanitary Measures, (Geneva: World Trade Organization), 29-49.

WTO (1998b), Sanitary and Phytosanitary Measures (The WTO Agreement Series), Geneva).

WTO (1999), 'Review of the Operation and Implementation of the Agreement on the Application of Sanitary and Phytosanitary Measures', (Geneva: World Trade Organization Committee on Sanitary and Phytosanitary Measures).

WTO (2008a), SPS Agreement Training Module, Geneva).

WTO (2008b), 'SPS Information Management System, http://spsims.wto.org/Default.aspx', WTO).

Zusman P. (1976), 'The incorporation and measurement of social power in economic models', International Economic Review, 17, 447-62. 
